

\title{
The Moral Economy of the Kolkhoz Worker, Or Why the Protest Movement in Belarus Does Not Seem to Concern the Collectivized Countryside
}

\author{
Ronan Hervouet
}

\section{- To cite this version:}

Ronan Hervouet. The Moral Economy of the Kolkhoz Worker, Or Why the Protest Movement in Belarus Does Not Seem to Concern the Collectivized Countryside. Slavic Review, 2021, 80 (1), pp.6168. 10.1017/slr.2021.23 . halshs-03254635

\section{HAL Id: halshs-03254635 \\ https://shs.hal.science/halshs-03254635}

Submitted on 25 Jan 2022

HAL is a multi-disciplinary open access archive for the deposit and dissemination of scientific research documents, whether they are published or not. The documents may come from teaching and research institutions in France or abroad, or from public or private research centers.
L'archive ouverte pluridisciplinaire HAL, est destinée au dépôt et à la diffusion de documents scientifiques de niveau recherche, publiés ou non, émanant des établissements d'enseignement et de recherche français ou étrangers, des laboratoires publics ou privés. 
The Moral Economy of the Kolkhoz Worker,

\section{Or Why the Protest Movement in Belarus Does Not Seem to Concern the Collectivized Countryside}

Ronan Hervouet (université de Bordeaux / Centre Émile Durkheim - UMR 5116)

Ronan Hervouet, "The Moral Economy of the Kolkhoz Worker, Or Why the Protest Movement in Belarus Does Not Seem to Concern the Collectivized Countryside ", Slavic Review, vol. 80, n 1, 2021, pp. 61-68.

Contact: ronan.hervouet@u-bordeaux.fr

Brief abstract:

The mass protests that have shaken Belarus since August 9, 2020 are occurring not only in the capital but also in provincial towns and even in smaller municipalities in Belarus. The protest does not seem to be affecting the countryside, however. This article, based on an ethnographic survey conducted in rural Belarus between 2006 and 2013, analyzes the roots of the attachment to Lukashenko's regime in these territories. The article describes the moral economy of kolkhozes, that is, the normative bases on which these social worlds are founded: equality, solidarity, and dignity. At the same time, the analysis reveals the figures of the moral offenders that rural inhabitants identify as posing a threat to their worlds: the profiteer, the idler, and the moralist. This defines the expectations toward politics that can be identified in the countryside, which essentially boil down to the conversion or punishment of these "moral offenders."

Brief biographical statement:

Ronan Hervouet is Professor of sociology at the University of Bordeaux (France) and a member of the Centre Émile Durkheim. He has published two books on Belarus, entitled Datcha blues. Existences ordinaires et dictature en Biélorussie (2009) and Le goût des tyrans. Une ethnographie politique du quotidien en Biélorussie (2020). The latter will be published in English in March 2021: A Taste for Oppression. A Political Ethnography of Everyday Life in Belarus (Berghahn Books). 
The mass protests that have shaken Belarus since August 9, 2020 are occurring not only in the capital, but also in provincial towns and even in smaller municipalities in Belarus. The forms of protest seen in the countryside appear to remain occasional and localized, however, even if it is difficult to ascertain their scale. The strikes, which hit many sectors of the economy in August 2020 and again in October 2020 - in the traditional industries but also in the information technology and service sectors - did not appear to affect the agricultural world. Forms of loyalty, or indeed attachment, to the incumbent authoritarian regime thus seem to be more common in the rural world, even today. This article, based on ethnographic research conducted in rural Belarus between 2006 and $2013^{1}$, analyzes the motives for the attachment to Lukashenka's regime in these areas.

Belarus is a country in which the share of the rural population remains significant, despite declining since the country became independent. Rural dwellers represented one third of the total population (34\%) in 1990 . Today, they amount to barely a quarter (23\%). The proportion of the labor force currently working in the agricultural sector is less than one person in ten (8\%), compared to almost one in five (19.1\%) in $1995 .^{2}$ From an economic standpoint, after a dramatic decline in its production in the early 1990s, the agricultural sector gradually improved its performance and started achieving results that were vaunted by the authorities: increased production, a slowdown in rural-tourban migration, and improved living conditions. These objectives were achieved by relying on the Soviet model for a collectivized countryside, which makes the Belarusian case a singular exception among post-communist paths of agricultural and rural development in Europe. ${ }^{3}$ In $2014,76.4 \%$ of

\footnotetext{
${ }^{1}$ I interviewed around forty people in different parts of the Belarusian countryside. I met some of them several times over the years. My sample covers a range of age cohorts (between the ages of twenty and eighty), comprising both working-age people and retirees, and includes kolkhoz workers, self-employed individuals, and teachers in agricultural high schools. The interviews were occasionally conducted in a structured manner and recorded on tape, but were usually carried out informally. I often initiated discussions in everyday situations (family meals, discussions about someone's working day, comments about the neighborhood, chats over a shared bottle of homemade wine or vodka, while relaxing in a bania, etc.). See Ronan Hervouet, "A Political Ethnography of Rural Communities under an Authoritarian Regime: The Case of Belarus," Bulletin de méthodologie sociologique / Bulletin of Sociological Methodology 141, no.1 (2019): 85-112.
}

\footnotetext{
${ }^{2}$ National Statistical Committee of the Republic of Belarus. "Sel'skoe khoziaistvo Respubliki Belarus"” (Agriculture in the Republic of Belarus). 2014.

${ }^{3}$ Contrary to decollectivization in the rest of the former USSR and eastern Europe. See Chris Hann, ed., The Postsocialist Agrarian Question: Property Relations and Rural Condition (Münster, 2003). The Soviet system of
} 
agricultural production came from the various public collective farms (still commonly referred to as "kolkhozes"), 1.5\% from small farmers, and 22.1\% from personal vegetable gardens. ${ }^{4}$ This collectivized structure is associated with a set of political, administrative, and moral injunctions that govern rural life. But can the obedience and loyalty to the regime witnessed in rural areas be attributed to economic results, on the one hand, and to the forms of supervision and control that are deployed in these territories, on the other? Analyses focusing on the effectiveness of state propaganda, cultural traditions, or a "social contract" that allows people to exchange their freedom for material rewards, seem to be insufficient to explain the forms of life and everyday politics in evidence on kolkhozes. ${ }^{5}$

This article describes the moral economy of the kolkhoz workers that is, the normative foundations on which their social worlds are based: equality, solidarity, and dignity. ${ }^{6}$ At the same time, the analysis sheds light on the figures of the "moral offenders" - profiteers, idlers, and moralistswhom inhabitants of rural areas identify as posing a threat to their worlds. ${ }^{7}$ This defines the political expectations that can be identified in rural worlds, which essentially boil down to the conversion or punishment of these moral offenders.

\section{The Material Organization of Everyday Life in Rural Belarus}

collective farms and state farms has stayed largely intact in Belarus. See Ronan Hervouet, Alexandre Kurilo and loulia Shukan, "Socialisme de marché et gouvernement des campagnes en Biélorussie," Revue d'Etudes comparatives Est-Ouest 48, no. 1-2 (2017): 85-120.

${ }^{4}$ National Statistical Committee of the Republic of Belarus. "Sel'skoe khoziaistvo Respubliki Belarus'” (Agriculture in the Republic of Belarus, 2014).

${ }^{5}$ In the Soviet case, this perspective maintains that the legitimacy of the authoritarian regime was based on a form of contractual exchange between the citizens and the authorities, with the former accepting reduced freedoms in exchange for the fulfillment of their material needs. See Stephen White, "Economic Performance and Communist Legitimacy," World Politics 38, no. 3 (1986): 462-482. In the Belarusian context, it is sometimes used to explain the perpetuation of Aleksandr Lukashenka 's regime. See Kirill Gaiduk, Elena Rakova, and Vitalii Silitskii, eds., Sotsial'nye kontrakty v sovremennoi Belarusi (Minsk, 2009).

${ }^{6}$ I defend the idea of there being a moral economy specific to the world of kolkhozes (the moral economy of the kolkhoz worker), as characterized by James Scott in the context of Southeast Asia: the moral economy of the peasant. See James C. Scott, The Moral Economy of the Peasant: Rebellion and Subsistence in Southeast Asia (New Haven, 1976).

${ }^{7}$ Michèle Lamont, The Dignity of Working Men: Morality and the Boundaries of Race, Class, and Immigration (Cambridge, Mass, 2000), 6. 
Adopting an ethnographic posture provides an insight into the practices adopted in this universe characterized by powerful economic, legal, and technical constraints. First of all, ethnographic fieldwork enables the researcher to describe the material organization of life in rural worlds, and the multiple and diverse resources that are mobilized in everyday practices. Some of these resources are official and authorized. For example, Belarusian villagers can legally increase their resources by cultivating their personal plots of land. Some of this production is destined for self-consumption, with the surplus being sold on markets. They can also enter into transactions with urban holidaymakers, engage in cross-border activities, or make profits from more marginal practices: exchange-rate speculation and the misappropriation of humanitarian aid or gifts and remittances in foreign currency made possible by the social mobility resulting from transnational marriages.

Certain illegal practices are also tolerated, easing constraints on kolkhoz workers at the local level and making their future more predictable. This may lead to kolkhoz workers not working, stealing the kolkhoz's products (potatoes, carrots, wood), either directly or by massaging the accounts (underestimating the weight of the meat produced and pocketing the difference for personal consumption, for example), pilfering the kolkhoz's resources (diesel, spare parts, construction materials), or borrowing machines without paying for their use (tractors to plow kolkhoz workers' own plots or harvest their own potato crop). My interlocutors' descriptions of these practices show that, as in the communist era, restrictive work organization systems are accompanied by different ways of misappropriating collective resources in order to improve one's own situation. ${ }^{8}$ In addition to the private use of collective resources (theft, robbery, misappropriation, accounting fraud), these illegal practices include distilling and distributing home-made alcohol and other types of less frequent practices such as poaching or prostitution.

\footnotetext{
${ }^{8}$ These practices are illustrations of the "institutionalized theft" observed by Gerald W. Creed, Domesticating Revolution: From Socialist Reform to Ambivalent Transition in a Bulgarian Village (University Park, 1998), 197; the "manipulable resources" analyzed by Caroline Humphrey, Marx Went Away-But Karl Stayed Behind: Updated Edition of Karl Marx Collective-Economy, Society, and Religion in a Siberian Collective Farm (Ann Arbor, 2001), 221; and the "sovkhoism" conceptualized by Yulian Konstantinov, Conversations with Power: Soviet and Post-Soviet Developments in the Reindeer Husbandry Part of the Kola Peninsula (Uppsala, Sweden, 2015).
} 


\section{Moral Communities}

The use of formal and informal resources enables people to satisfy material expectations and to feel what anthropologist Yulian Konstantinov calls "a sense of existential security." ${ }^{9}$ The material expectations differ between age cohorts. They are strictly limited among elderly people, and moderate in the post-war generations. While everyone's expectations cannot be met, especially among the young people who seem to be more readily critical of the regime, the majority of the people interviewed seem to agree that their lot in life is acceptable and that the system allows them to attain levels of well-being that can even be defined as desirable.

This material organization of daily life has moral implications. Indeed the use of formal and informal resources is rooted in various forms of reciprocity and solidarity. In the interviews, the exchanges of goods and services are sometimes described in terms of a quid pro quo or as a balanced transaction (principle of reciprocity), but also-and more commonly-in terms of gifts and countergifts, or as an altruistic practice (principle of solidarity). ${ }^{10}$ The solidarity perceived and implemented appears to be a consequence of specific behaviors adopted to help people endure the complex system of pressures exerted by the kolkhoz hierarchy and the governing authorities. These problems can only be overcome by the mobilization of numerous interdependent actors. Coping with these difficulties requires mutual aid. In this manner, the regime, by producing and tolerating an "economy of favors," indirectly generates a feeling of practical solidarity among Belarusian villagers. ${ }^{11}$

\footnotetext{
${ }^{9}$ Yulian Konstantinov, "'The Magic 'Tablecloth': Personal Property and Sovkhoism in Soviet and Post-Soviet Russia," Region: Regional Studies of Russia, Eastern Europe, and Central Asia 9, no. 1 (2020): 8.

${ }^{10}$ Take the example of participation in subbotniki, the days of voluntary work organized on certain Saturdays of the year-a legacy of the "Communist Saturdays" introduced by Lenin in 1919. See Ronan Hervouet and Alexandre Kurilo, "Travailler 'bénévolement' pour la collectivité: Les subbotniki en Biélorussie postsoviétique," Genèses. Sciences sociales et histoire 78, no.1 (2010): 87-104. Participating in the subbotnik is a way to avoid causing problems for the local organizer of the event. If the activities are not carried out satisfactorily by a sufficient number of people, the person in charge may indeed be punished. As a consequence, he or she becomes indebted to the participants, and in return will allow the participants to obtain material benefits from the event, gain access to specific services, or take advantage of certain concessions in the organization of work. For these reasons, subbotniki can be seen as the embodiment of a form of solidarity, asserting the existence of an "us," i.e. a group of individuals who are highly interdependent at the local level. This is the sense in which participation in subbotniki is mentioned discursively as a duty that relates to a practical sense of everyday solidarity.

11 "Those actions which appear to mix instrumental and affective relations, goal oriented and gift exchanges, and 'formal' and 'informal' institutional ties." See Nicolette Makovicky and David Henig, "Introduction: Re-imagining
} 
Finally, ethnographic analysis also reveals how the system generates forms of dignity that enable the acquisition of social worth in local settings. External perspectives on kolkhozes generally focus on the difficult working conditions, low wages, disorganized production, harsh social relations, and alcoholism. My interlocutors, however, perceive the collectivist system of organization as allowing people to lead dignified and meaningful lives, since they enable the manifestation of sociallyrecognized qualities, either within the structure of the kolkhoz or outside it (by working on a personal plot of land, tending beehives, building one's own house, or even by hunting or fishing). These qualities are endurance, ingenuity, enthusiasm, and a sense of independence. The economic and administrative constraints generated by the regime are not seen as the embodiments of an oppressive system but rather as an order of things that must be appropriated in order to construct one's own universe. ${ }^{12}$

In this way, the world of the collectivized countryside can be perceived as fair. I am not arguing that it is fair, but simply explaining why it may appear to be fair in my interlocutors' eyes. They do not perceive this world to be fundamentally unfair, because their practical experience is structured by principles that make sense to them: equality, merit, autonomy, and solidarity are possible in this world, and enable people to lead dignified and meaningful lives in it.

\section{Moral Offenders}

In everyday conversations, people comment upon, discuss, and denounce unfair situations. Examining experiences and representations of injustice makes it possible to document how rural dwellers relate to everyday politics. In fact, the question of the regime's legitimacy is raised only rarely in these

Economies (after Socialism): Ethics, Favors, and Moral Sentiments," in Nicolette Makovicky and David Henig, eds., Economies of Favour after Socialism (Oxford, 2017), 3.

${ }^{12}$ This echoes Alena Ledeneva's analysis of the emotions aroused by practices of blat in the Soviet era, which enable people to express their intelligence, efficiency, and creativity-their "ability to get things done." She concludes that when workers manage to "beat the system," they take control of their destiny, and the rewards they can gain are not only monetary: Alena V. Ledeneva, Russia's Economy of Favours: Blat, Networking and Informal Exchange (Cambridge, 1998), 56-58 and 162. In communist Poland, Janine Wedel also notes the "satisfaction" of successfully bending the rules of the system. See Janine R. Wedel, The Private Poland: An Anthropologist's Look at Everyday Life (New York, 1986), 31. In Belarus today, resourcefulness and cunning are also valued qualities. 
conversations. ${ }^{13}$ Consequently, there is no discussion of politics in the sense of exchanges of views about the validity of the rules governing collective life. What people do mention is that the system is being undermined by menacing behaviors that are challenging and damaging the foundations on which "moral communities" are based. ${ }^{14}$ These behaviors are not explained as products of the organization of social and economic life but as a consequence of the offenders' lack of morality. In informal discussions that occur during the course of daily life, certain types of behavior are mentioned in modes of denunciation and criticism. People who exhibit these behaviors can be divided into three types: profiteers, idlers, and moralists. Rather than being explicit designations, these types are unofficial counter-models, opposed to the morality upheld by the local community, which can be reconstructed by the sociologist from implicit references by the inhabitants of rural communities.

Profiteers are people who offend the values that define the boundaries of the moral community. Because they work only for their own gain and without concern for others, they are assumed to be exploiting the locals and ignoring the principle of equality that governs social relations. Profiteers, because they use and instrumentalize others, do not enrich themselves through their own efforts, but rather by appropriating the work carried out by others. This confiscation of the value produced by other people conflicts with the principle of dignity, based on merit and self-reliance. But above all, profiteers are people who subvert the principle of solidarity. They do not think twice about harming others for their personal gain. They rank their own interests and self-love above the common morality. They only fulfill their duties if it does not interfere with their own happiness.

The second figure is the idler who lacks the will to work. The alcoholic is the paradigmatic embodiment of this figure. Alcoholics break with the values dear to the local rural community. They are tolerated but cannot pretend that their actions are driven by a sense of moral duty, honesty

\footnotetext{
${ }^{13}$ This situation is linked to the Belarusian authoritarian context. In other post-communist countries, research shows that rural dwellers explicitly express their own opinions and views on politics. For example, see: Anna Malewska-Szałygin, Social Imaginaries of the State and Central Authority in Polish Highland Villages, 1999-2005 (Cambridge, Eng., 2017).

${ }^{14}$ Lamont, The Dignity of Working Men, 9.
} 
towards the community, or altruism. They cannot belong to the "us" developed by exchanges in the form of gifts and counter-gifts. They are also unable to attain dignity, which implies independence, as they depend on the daily dose of vodka they require in order to maintain control over their bodies. They are perceived as dishonest, bone-idle, and selfish.

Profiteers and idlers are characters without morals. The third menacing figure is embodied by anyone who presents an alternative morality that conflicts with the morality that is shared locally. Contrary to the profiteers and the idlers, moralists do not subvert the current system from within. They occupy a position of exteriority. In this perspective, moralists are moral offenders because they invalidate the current system from the outside; they delegitimize it and look down upon it. Two characters are perceived as bearers of alternative moralities. In certain cases, urbanites are considered to possess a morality based on materialism. Negative judgments are often directed at urbanites first and foremost, especially the dachniki-holiday residents who visit rural areas. The other figures who are sometimes mentioned directly, but more often crop up in conversations, are members of the political opposition and human rights activists. Belarusian villagers know them essentially through the official media-they become more visible when campaigning prior to elections, or when they are contesting election results. In certain cases, they are very simply reduced to the role of opportunists and unscrupulous profiteers who do not believe in what they say but criticize the regime in order to attract more aid from foreign powers. They can also be perceived as idlers because they perform no "honest" work, as it is locally defined. On a more fundamental level, however, they are seen above all as scandalous figures who challenge the order on which people's existences are based. By refusing to play by the established rules, and by talking about democracy, Europe, and the market, they are perceived by my interviewees as denying any value to the fundamental dignity to which they themselves lay claim. Opposition to the defenders of civil liberties implicitly reveals an attachment to a life world with a consistency of its own, in which the sense of creating a self-sufficient existence for oneself is detached from the political and constitutional conditions required for exercising freedom of thought. These conditions are not seen as necessary for personal emancipation but rather as heralding 
the collective downfall of rural moral communities. Proof of this is found in the post-socialist experiments that have turned rural worlds upside down. The situation in several regions of the former USSR, such as Russia and Ukraine during the 1990s, as presented by the media but especially in accounts shared by acquaintances or family members, acts as a disincentive to change.

\section{Everyday Politics}

In the world of the kolkhoz, everyday politics are not structured by theoretical constructs and deliberative choices, and are far from the ordinary conception of the political game, surveys, and political intellectuals. They are an extension of moral judgments linked to the coherence of people's own life worlds. ${ }^{15}$ The classical notion of a "moral economy" is useful here because it highlights the ties between everyday practices and values, and concrete expectations of politics. ${ }^{16}$ On the one hand, it refers to the values shared by a population, values on which its conceptions of what is fair or unfair, tolerable, or intolerable, acceptable or scandalous are based. On the other hand, it stresses the modalities of action that the authorities must deploy when these principles of ordinary ethics are not respected.

At first, the rural dwellers I encountered expect the authorities to tolerate the moderate use of illegal resources that enable honest people to live decently in return for a minimal engagement at work, and then, they expect them to convert, or possibly punish, the figures who jeopardize this social order-in short, to protect these fair worlds. The three controversial figures-the profiteer, the idler,

\footnotetext{
15 This remoteness from formal politics (work of political parties, influence of associative life on social movements, etc.) is obviously not a specificity of the kolkhoz workers' attitudes toward politics. Generally speaking, one of the aims of political ethnography is precisely to observe and analyze everyday politics in various national and social contexts. See Claudio E. Benzecry and Gianpaolo Baiocchi, "What is Political about Political Ethnography? On the Context of Discovery and the Normalization of an Emergent Subfield," Theory and Society 46, no. 3 (2017): 229-47. In the Belarusian context, it can also be hypothesized that the recent forms of urban dwellers' politicization also have their origins in everyday politics, and not only in deliberations on formal politics.

${ }^{16}$ Reflecting on the food riots in seventeenth-century England, Edward P. Thompson describes "a consistent traditional view of social norms and obligations, of the proper economic functions of several parties within the community, which, taken together, can be said to constitute the moral economy of the poor," Edward P. Thompson, Customs in Common (London, 1991), 188.
} 
and the moralist-tell us a lot about people's expectations of politics. The threat of disorder appears to reside in a lack of morality that can only be corrected by control and conversion. If benevolent paternalistic practices are insufficient, then recourse to violence seems legitimate. This expectation vis-à-vis the authorities appears either in the form of explicit justifications for coercive measures adopted by the regime, or as an indifference regarding these measures when they target moral offenders.

The use of physical violence is seen as self-evidently justified. The fact that kolkhoz directors and administrative managers are regularly punished, imprisoned, and sentenced after being interrogated by the police or security services clearly shows that the system must defend itself against those who act in pursuit of their own interests. Resisting encroachment by others is seen as essential so everyone can navigate life and poach what they need in this world. Consequently, when the president, in his speeches, insists on the use of force to maintain order in the country, it becomes apparent that his declarations echo the attitudes of rural dwellers. This makes the strong state appear as a protective force, even though objectively speaking it potentially poses a threat to every one of its citizens. As a consequence, kolkhoz workers tend to defend Lukashenka because he has the power to bring down anyone, including the most powerful, and is thus regarded as a last resort, a kind of Grand Inquisitor figure. The absence of a powerful, centralized regulatory authority could lead to radical disorder because there would no longer be any scope for expressing moral sentiments, which would be annihilated by unscrupulousness and self-interest. Without violence, the profiteers and their radical incarnations - the "bandits" - would reign supreme, as they did in Russia during the 1990s.

Has the wave of protest that is sweeping Belarus also reached rural areas, which are traditional hotbeds of support for the regime? On-the-spot analyses of events propose different explanations for these protests, whose scale is unprecedented in the history of the country: from an exacerbation of economic difficulties over recent months and the stagnation of wages, or the arrogance of a president 
who has not only failed to manage the COVID health crisis but also repeatedly made disparaging comments and humiliated victims of the virus by holding them responsible for their illness, to the unexpected success of the election campaign by Sviatlana Tsikhanouskaya, whose candidature was only authorized because she was perceived as politically harmless. It is very difficult to know what is happening in rural areas, among the kolkhoz workers, whose silence after August 9 was not least due to the fact that they were busy in the fields during peak harvest time. The protests have spread beyond Minsk and the major cities, and have certainly reached small towns and villages. We know that the feeling of alienation from the president, and even of distrust or rejection, has spread to a proportion of kolkhoz workers, just as it has affected some other workers. It is difficult, however, to grasp the extent and degree to which it has spread to the collectivized countryside. This probably depends on various factors: the economic health of the kolkhoz, the age cohort, the director's personality, and proximity to major urban centers. Reliable information about this issue is lacking. It can be hypothesized, however, that the factors triggering the protests in the city have not profoundly changed the moral economy of the kolkhoz worker. Consequently, the drivers of support for the regime identified in rural areas ten years ago appear to be valid today. The divergence between political expectations in the urban and rural worlds seems to be increasing, and these growing differences can be seen as a clear illustration of the gradual fragmentation of the country. 